\title{
Direct Detection of Escherichia coli Virulence Genes by Real-Time PCR in Fecal Samples from Bats in Brazil
}

\begin{abstract}
Adriana Cabal, ${ }^{1,2}$ Maria J. Pereira, ${ }^{3,4,5}$ Ludmilla M. S. Aguiar, ${ }^{6}$ Lucas Domínguez, ${ }^{1}$ Carlos Fonseca, ${ }^{5}$ Julio Álvarez, ${ }^{7}$ Jan F. Drexler, ${ }^{8}$ and Christian Gortázar ${ }^{2,9}{ }^{1}$ VISAVET Health Surveillance Centre, Complutense University of Madrid, Avenida Puerta de Hierro s/n 28040 Madrid, Spain; ${ }^{2}$ SaBio IREC (CSICUCLM-JCCM), Ronda de Toledo s/n 13071 Ciudad Real, Spain; ${ }^{3}$ PPGBAN, Department of Zoology, Institute of Biosciences, Federal University of Rio Grande do Sul, Avenida Bento Gonçalves 9500, Porto Alegre Rio Grande do Sul, 91540-000, Brazil; ${ }^{4}$ PPGEC, Federal University of Mato Grosso do Sul, Campo Grande, Mato Grosso do Sul, 79090-900, Brazil; ${ }^{5}$ Department of Biology and Center for Environmental and Marine Studies, University of Aveiro, Campus Universitário de Santiago, Aveiro 3810-193, Portugal; ' ${ }^{6}$ Department of Zoology and Institute of Biological Sciences, University of Brasília, Campus Darcy Ribeiro, 70.910-900 Distrito Federal, Brazil; ${ }^{7}$ Department of Veterinary Population Medicine, College of Veterinary Medicine, University of Minnesota, 1352 Boyd Ave., St. Paul, Minnesota, USA; ${ }^{8}$ Institute of Virology, University of Bonn Medical Centre, Sigmund-FreudStr. 25 Bonn 53127, Germany; ${ }^{9}$ Corresponding author (email: Christian.Gortazar@uclm.es)
\end{abstract}

ABSTRACT: Guano samples from 412 Brazilian bats were screened with real-time PCR for the virulence genes (eae, est, elt, stx $1, s t x 2$, ehxA inv $\mathrm{A}, b f p \mathrm{~A}, \operatorname{agg\mathrm {R}})$ representing five intestinal pathotypes of Escherichia coli. From 82 pooled samples, 22\% contained Escherichia coli DNA, and eae, est, bfp A, aggR were detected.

Bats (Chiroptera) are a taxonomically and ecologically diverse group of animals found in almost all habitats and trophic levels. With 1,152 species of bats currently documented (Reeder and Wilson 2005; Schipper et al. 2008), they are recognized as a natural reservoir for a wide range of viral pathogens, some of which can cause severe disease in humans (e.g., RNA viruses, such as rabies, Ebola, and Nipah viruses; Leroy et al. 2005; Castilho et al. 2010; Kuzmin et al. 2011). In contrast, little is known about bats as carriers of pathogenic bacteria because only a few authors have investigated enteric bacteria, including Escherichia coli, in bats (Chaverri 2006; Adesiyun et al. 2009; Oluduro 2012; Muhldorfer 2013).

Escherichia coli is a commensal bacterium found in the intestine of mammals and birds, with a higher prevalence reported in herbivores and omnivores compared with carnivores, marsupials, and bats (Gordon and Cowling 2003). Information concerning the prevalence of E. coli in bats is scarce. Previous research has shown that only a low proportion of bats are carrying $E$. coli, which could be due to the lack of a cecum and, thus, microbial fermentation in these animals (Gordon and Cowling 2003). However, E. coli has been reported as the cause of urinary tract infection in Vespertilionid bats (Muhldorfer 2013).

To advance epidemiologic knowledge of E. coli in bats, we investigated the presence of $E$. coli in guano of Brazilian bats. We captured 412 bats at 27 sampling points in the Serra do Lajeado Environmental Protection Area, Tocantins State, Brazil $\left(10^{\circ} 2^{\prime} 47.79^{\prime \prime} \mathrm{S}, \quad 48^{\circ} 15^{\prime} 45.11^{\prime \prime} \mathrm{W}\right)$, using mist-nets. Sampling occurred April-June and October-December in 2012 and 2013 and included three replicates of pristine areas and three replicates of areas subjected to two levels of anthropogenic modification. Mild changes included removal of native trees and planting of trees with economic interest. Areas with severe modifications were characterized by widespread tree removal. Each captured bat was identified and weighed before release. Fecal samples were collected immediately after bats were taken, directly from the animal (no swabs were used). We collected 412 individual fecal samples from 33 species of bats in four families (Table 1), including nectarivores, frugivores, insectivores, and omnivores. Samples 
TABLE 1. Bat species (suborder Microchiroptera), feeding habits, and genotypes found in each pool of DNA from samples of guano from bats collected in Tocantins State, Brazil, 2012 and 2013.

\begin{tabular}{|c|c|c|c|}
\hline Bat family, species & Feeding ${ }^{\mathrm{a}}$ & No. of samples & $\begin{array}{c}\text { Pool pattern } \\
\text { (No. of positive pools) }\end{array}$ \\
\hline \multicolumn{4}{|l|}{ Phyllostomidae } \\
\hline Anoura caudifer & $\mathrm{N}$ & 2 & 0 \\
\hline Anoura geoffroyi & $\mathrm{N}$ & 5 & st $(1)$ \\
\hline Artibeus concolor & $\mathrm{F}$ & 2 & $\operatorname{agg\mathrm {R}}(1), e a e / b f p \mathrm{~A} / s t(1)$ \\
\hline Artibeus glaucus & $\mathrm{F}$ & 2 & $\operatorname{aggR}(1)$ \\
\hline Artibeus gnomus & $\mathrm{F}$ & 1 & 0 \\
\hline Artibeus lituratus & $\mathrm{F}$ & 8 & $b f p \mathrm{~A}(1)$ \\
\hline Artibeus obscurus & $\mathrm{F}$ & 3 & 0 \\
\hline Artibeus planirostris & $\mathrm{F}$ & 1 & 0 \\
\hline $\begin{array}{l}\text { Artibeus planirostris/ } \\
\text { A. fraterculus }\end{array}$ & $\mathrm{F}$ & 28 & bfp A (1), eae (2), eae/bfp A (1) \\
\hline Carollia perspicillata & $\mathrm{F}$ & 286 & $\begin{array}{c}\text { eae (6), bfp } \mathrm{A}(2), \text { st (3), aggR (1), } \\
\text { eae/bfp }(2), \text { eae/bfp } \mathrm{A} \text { est (1) }\end{array}$ \\
\hline Glossophaga soricina & $\mathrm{N}$ & 4 & eae $(1)$ \\
\hline Lonchophylla dekeyseri & $\mathrm{N}$ & 4 & 0 \\
\hline Lonchophylla mordax & $\mathrm{N}$ & 3 & 0 \\
\hline Lonchophylla mordax/dekeyseri & $\mathrm{N}$ & 1 & $\operatorname{agg} \mathrm{R}(1)$ \\
\hline Lonchophylla sp. & $\mathrm{N}$ & 5 & eae (1), eae/bfp $\mathrm{A} / s t$ (1) \\
\hline Lonchorhina aurita & I & 4 & eae (1) \\
\hline Lophostoma carrikeri & I & 1 & $b f p \mathrm{~A}(1)$ \\
\hline Lophostoma silvicola & I & 2 & 0 \\
\hline Micronycteris megalotis & I & 1 & eae (1) \\
\hline Mimon crenulatum & I & 4 & eae (2) \\
\hline Phyllostomus hastatus & $\mathrm{O}$ & 3 & 0 \\
\hline Platyrrhinus helleri & $\mathrm{F}$ & 8 & 0 \\
\hline Rhinophylla pumilio & $\mathrm{F}$ & 2 & eae/bfp $\mathrm{A} / s t$ (1) \\
\hline Sturnira lilium & $\mathrm{F}$ & 3 & $e a e / b f p \mathrm{~A}(1)$ \\
\hline Sturnira tildae & $\mathrm{F}$ & 6 & eae/bfp A (1) \\
\hline Tonatia saurophilla & I & 1 & eae (1) \\
\hline Uroderma bilobatum & $\mathrm{F}$ & 1 & 0 \\
\hline Vampirodes caracciolli & $\mathrm{F}$ & 4 & 0 \\
\hline \multicolumn{4}{|l|}{ Emballonuridae } \\
\hline Saccopteryx canescens & $\mathrm{I}$ & 2 & $e a e / b f p \mathrm{~A}(1)$ \\
\hline Saccopteryx leptura & I & 1 & eae (1) \\
\hline \multicolumn{4}{|l|}{ Vespertilionidae } \\
\hline Myotis albescens & I & 1 & st (1) \\
\hline Myotis nigricans & I & 1 & 0 \\
\hline Myotis riparius & I & 3 & st (1) \\
\hline Rhogeessa io & I & 1 & eae (1) \\
\hline \multicolumn{4}{|l|}{ Mormoopidae } \\
\hline Pteronotus parnellii & I & 4 & eae (1) \\
\hline Unknown & & 4 & 0 \\
\hline Total & & 412 & \\
\hline
\end{tabular}

${ }^{\text {a }} \mathrm{N}=$ nectarivore, $\mathrm{F}=$ frugivore, $\mathrm{I}=$ insectivore, $\mathrm{O}=$ omnivore.

${ }^{\mathrm{b}}$ The pool pattern can be duplicated because different species comprise each pool.

were preserved in $500 \mu \mathrm{L}$ of RNAlater to a final volume of $100 \mu \mathrm{L}$ in each pool RNA stabilization reagent (QIAGEN, (belonging to different species and sampling Lisbon, Portugal), stored at $4 \mathrm{C}$, and analyzed points).

6-12 mo after collection. We extracted DNA from all samples individually with a commercial kit, and $20 \mu \mathrm{L}$ of each was pooled

The DNA was analyzed by real-time PCR in pools $(n=82)$ for nine $E$. coli virulence genes (VGs) characteristic of five pathotypes 
TABle 2. Prevalence (95\% confidence intervals [CI]) of single virulence genes and patterns detected by real-time PCR of pools of DNA from samples of guano from bats collected in Tocantins State, Brazil, 2012 and 2013.

\begin{tabular}{lcc}
\hline \multicolumn{1}{c}{ Target } & $\begin{array}{c}\text { Positive pools } \\
(n=82)\end{array}$ & \multicolumn{1}{c}{$\begin{array}{c}\text { (exact } 95 \% \\
\mathrm{CI})\end{array}$} \\
\hline uidA & 18 & $4.84(2.87-7.55)$ \\
Eae & 16 & $4.25(2.43-6.82)$ \\
bfpA & 5 & $1.25(0.41-2.89)$ \\
est $(\mathrm{ST})$ & 2 & $0.49(0.06-1.77)$ \\
aggR & 1 & $0.25(0.01-1.36)$ \\
ehxA & 0 & 0 \\
stx 1 & 0 & 0 \\
stx2 & 0 & 0 \\
invA & 0 & 0 \\
elt $(\mathrm{LT})$ & 0 & 0 \\
eae/bfpA & 3 & $0.74(0.15-2.15)$ \\
eae/bfpA/est & 1 & $0.25(0.01-1.36)$ \\
\hline
\end{tabular}

affecting humans (enterohemorrhagic E. coli [EHEC], enteroaggregative E. coli [EAEC], enteropathogenic E. coli [EPEC], enteroinvasive E. coli [EIEC], and enterotoxigenic E. coli [ETEC]) using previously published primers (Cabal et al. 2013) and newly designed TaqMan probes (available under request). The VGs associated with each pathotype were $s t x 1, s t x 2$, eae, and $e h x \mathrm{~A}$ for EHEC; $\operatorname{aggR}$ for EAEC; elt and est for ETEC; eae and $b f p \mathrm{~A}$ for EPEC; and invA for EIEC. A genus-specific gene (uidA) was also included in the PCR assay to estimate the prevalence (WINPEPI updated, version 11.35) of total E. coli in each pooled sample. Analysis was conducted using WINIPEPI version 11.35 (Abramson 2011). No culture isolation methods were applied.

Of 82 pooled samples, $18(22 \%)$ were positive for E. coli (uidA gene), but four VGs characteristic of EPEC, ETEC, and EAEC pathotypes were also detected (Table 2). One sample positive for $b f p \mathrm{~A}$ was sequenced and confirmed as E. coli O157:H45.

Our results ( $22 \%$ positive) were in agreement with those from other authors who reported 11-28\% positive samples (Pinus and Müller 1980; Adesiyun et al.
2009; Apun et al. 2011). In addition, we showed that some VGs (eae, bfp A, est, $\operatorname{aggR}$ ) were present in bat feces, suggesting the presence of pathogenic E. coli. The pathotypes present in guano may include EAEC, typical EPEC, and ETEC strains. No indications of STEC- or EIEC-associated VGs were seen. This supports Apun et al. (2011) who found no EHEC-positive samples in bats. In the literature, we found no animal reservoirs reported for other pathotypes different from STEC, but previously (Cabal et al. 2013), we showed that typical human E. coli VGs might be more widespread in animals than commonly believed. In addition, the sequenced DNA product matching an O157:H45 strain in one pooled sample suggested the presence of atypical EPEC in bats. This serotype was described as a causative agent of enterocolitis and sporadic diarrhea in humans (Stephan et al. 2004). Detection of multiple VGs within pooled samples does not imply that a single bacterium is carrying them simultaneously. In addition, it is unknown whether bats were infected with pathogenic $E$. coli or were temporary carriers of these pathogens. It is possible that, because of their feeding habits and the physiology of their digestive tract (Gordon and Cowling 2003), bats may become transiently infected by using farms or urban areas as foraging grounds (Chaverri 2006).

Although plating of the VG-positive samples will be necessary, isolation might be complicated, given the low proportion of VGs. Therefore, the possibility of bats being infected with pathogenic E. coli cannot be excluded, and further research is needed to elucidate the role bats may have in the epidemiology of human infections with important pathovars of $E$. coli.

Bats were collected under permits from the Brazilian Ministry of Science and Technology (343, 2012), Sisbio (33542, 2012) and Naturatins (1633, 2012). We thank K. VanderWaal for her contribution to the manuscript. Research was supported 
by European Union FP7 ANTIGONE (Anticipating the Global Onset of Novel Epidemics) project 278976.

\section{LITERATURE CITED}

Abramson JH. 2011. WINPEPI updated: Computer programs for epidemiologists, and their teaching potential. Epidemiol Perspect Innov 8:1. http:// www.ncbi.nlm.nih.gov/pmc/articles/PMC3041648/ pdf/1742-5573-8-1.pdf. Accessed June 2015.

Adesiyun AA, Stewart-Johnson A, Thompson NN. 2009. Isolation of enteric pathogens from bats in Trinidad. J Wildl Dis 45:952-961.

Apun K, Kho KL, Chong YL, Hashimatul FH, Abdullah MT, Rahman, MA, Lesley MB, Samuel L. 2011. Detection of Escherichia coli O157:H7 in wildlife from disturbed habitats in Sarawak, Malaysia. Res J Microbiol 6:132-139.

Cabal A, Gomez-Barrero S, Porrero C, Barcena C, Lopez G, Canton R, Gortazar G, Dominguez L, Alvarez J. 2013. Assessment of virulence factors characteristic of human Escherichia coli pathotypes and antimicrobial resistance in O157:H7 and non-O157:H7 isolates from livestock in Spain. Appl Environ Microbiol 79:4170-4172.

Castilho JG, Carnieli P Jr, Oliveira RN, Fahl WO, Calvacante R, Santana AA, Rosa WL, Carrieri ML, Kotait I. 2010. A comparative study of rabies virus isolates from hematophagous bats in Brazil. J Wildl Dis 46:1335-1339.

Chaverri G. 2006. Aerobic bacterial flora from the digestive tract of the common vampire bat, Desmodus rotundus (Chiroptera: Phyllostomidae). Rev Biol Trop 54:717-724.

Gordon DM, Cowling A. 2003. The distribution and genetic structure of Escherichia coli in Australian vertebrates: Host and geographic effects. Microbiology 149:3575-3586.

Kuzmin IV, Bozick B, Guagliardo SA, Kunkel R, Shak JR, Tong S, Rupprecht CE. 2011. Bats, emerging infectious diseases, and the rabies paradigm revisited. Emerg Health Threats J 4:7159.

Leroy EM, Kumulungui B, Pourrut X, Rouquet P, Hassanin A, Yaba P, Delicat A, Paweska JT, Gonzalez JP, Swanepoel R. 2005. Fruit bats as reservoirs of Ebola virus. Nature 438:575-576.

Muhldorfer K. 2013. Bats and bacterial pathogens: A review. Zoonoses Public Health 60:93-103.

Oluduro AO. 2012. Antibiotic-resistant commensal Escherichia coli in faecal droplets from bats and poultry in Nigeria. Vet Ital 48:297-308.

Pinus M, Müller HE. 1980. Enterobacteria of bats (Chiroptera). Zentralbl Bakteriol A 247:315-322. [In German.]

Reeder DM, Wilson DE. 2005. Mammal species of the world: A taxonomic and geographic reference. 3rd ed. Johns Hopkins University Press, Baltimore, Maryland, 2,142 pp.

Schipper J, Chanson JS, Chiozza F, Cox NA, Hoffmann M, Katariya V, Lamoreux J, Rodrigues ASL, Stuart SN, Temple HJ, et al. 2008. The status of the world's land and marine mammals: Diversity, threat, and knowledge. Science 322:225-230.

Stephan R, Borel N, Zweifel C, Blanco M, Blanco J. 2004. First isolation and further characterization of enteropathogenic Escherichia coli (EPEC) O157: H45 strains from cattle. BMC Microbiol $4: 10$.

Submitted for publication 30 January 2015. Accepted 23 April 2015. 